\title{
DARIUSZ KLIMEK
}

Politechnika Łódzka, Polska

Lodz University of Technology, Poland

\section{Zmiany strukturalne w polskim przemyśle zbrojeniowym}

\section{Structural Changes in the Polish Arms Industry}

Streszczenie: Przedmiotem artykułu są zmiany strukturalne w przemyśle zbrojeniowym w Polsce po 1990 roku na tle przeobrażeń, jakie zachodziły w tym przemyśle na świecie, w tym w szczególności związane z konsolidacją przedsiębiorstw. Celem artykułu jest znalezienie odpowiedzi na dwa pytania dotyczące obecnej struktury polskiego przemysłu zbrojeniowego. Pierwsze pytanie to - w jakim stopniu ta struktura jest podobna do modelu koncentracji przemysłu zbrojeniowego w USA i Europie Zachodniej. Drugie - czy struktura polskiego przemysłu zbrojeniowego jest odpowiednia do odbudowy pozycji tego przemysłu na światowym rynku zbrojeniowym w warunkach stopniowego ograniczania barier protekcjonistycznych w Europie. Aby zrealizować cel artykułu, zastosowano różne metody badawcze. Podstawowa to analiza polskiej i zagranicznej literatury przedmiotu oraz niepublikowanych materiałów z byłego Ministerstwa Gospodarki. Druga to metoda jakościowa z wykorzystaniem techniki wywiadu swobodnego. Autor przeprowadził wywiady z prawie 20 szefami polskich firm zbrojeniowych w trakcie kilku targów specjalistycznych sprzętu i uzbrojenia wojskowego w 2016 i 2017 roku. Podstawowe wnioski z badań nie są optymistyczne. O ile struktura polskiego przemysłu zbrojeniowego jest w niewielkim zakresie zbliżona do rozwiązań, jakie przyjęto w USA i Europie Zachodniej, raczej bliższa jest modelowi koncentracji w narodowe struktury (holdingi i koncerny) charakterystyczne dla państw Europy Środkowo-Wschodniej, o tyle sam proces koncentracji następował zbyt powoli i w sposób nieco przypadkowy. Głównym problemem jest jednak to, że tak ukształtowana struktura nie zapewnia poprawy konkurencyjności polskiego przemysłu zbrojeniowego wobec szybko nadchodzących zmian w europejskim przemyśle zbrojeniowym.

\footnotetext{
Abstract: The subject of this article are the structural changes in the armaments industry in Poland after 1990 regarding the background of worldwide transformations that took place at that time, in particular related to the consolidation of enterprises. The aim of the article is to provide answers to the following questions about the current structure of Polish armaments industry. First - to what extent is the structure similar to the concentrated model of the USA and Western Europe arms industry? Second - is the structure of Polish arms industry suitable for rebuilding its position on the global armaments market in the conditions of gradual reduction of protectionist barriers in Europe? Various research methods have been used to achieve the goal of the article. The basic one becomes the analysis of Polish and foreign literature of the subject and unpublished materials from the former Ministry of Economy. The second method - qualitative - uses the technique of free interview. The author interviewed nearly 20 chief-executive officers of Polish armament companies during several specialist military equipment and armament fairs in 2016 and 2017. The basic conclusions of the research are not optimistic. While the structure of Polish arms industry is not very close to the solutions applied in the US and Western Europe, it is more related to the concentrated models in national structures (holdings
} 
and concerns) characteristic for Central and Eastern European countries, the process of concentration was executed too slowly and in a random way. Nevertheless, the main problem is that existing structure does not improve the competitiveness of the Polish arms industry in the face of dynamic changes in the European one.

Słowa kluczowe: koncentracja przedsiębiorstw; przemysł zbrojeniowy; struktura przemysłu; zmiany strukturalne

Keywords: arms industry; concentration of enterprises; industry structure; structural changes

Otrzymano: 18 grudnia 2017

Received: 18 December 2017

Zaakceptowano: 5 lipca 2018

Accepted: 5 July 2018

Sugerowana cytacja / Suggested citation:

Klimek, D. (2018).Zmiany strukturalne w polskim przemyśle zbrojeniowym. Prace Komisji Geografii Przemysłu Polskiego Towarzystwa Geograficznego, 32(3), 144-156. https://doi.org/10.24917/20801653.323.9

\section{WSTĘP}

Przemysł zbrojeniowy trudno zaklasyfikować jako osobny dział przemysłu. Każda branża przemysłu maszynowego, precyzyjnego, stoczniowego, lotniczego, elektronicznego i wielu innych produkuje coś na potrzeby wojska. W opracowaniach GUS nie ma pojęcia ani wykazu wyrobów przemysłu zbrojeniowego, mieszczą się one najczęściej w wyrobach różnych przemysłów. Brak wyodrębnienia tego przemysłu nie oznacza jego niewielkiego znaczenia w gospodarce światowej. Świadczą o tym dane dotyczące wydatków wojskowych i wydatków na sprzęt i uzbrojenie kupowane w przemyśle zbrojeniowym. Według Sztokholmskiego Instytutu Badań nad Pokojem (SIPRI, 2017) światowe wydatki wojskowe w 2016 roku zostały oszacowane na 1,7 bln dol., co odpowiada 2,2\% globalnego produktu krajowego brutto lub alternatywnie 227 dol. na każdego obywatela naszego globu. Razem globalne wydatki w 2016 roku były w przybliżeniu stałe w porównaniu do 2015 roku, będąc tylko o 0,4\% wyższe w ujęciu realnym. Wydatki wojskowe w Ameryce Północnej odnotowały pierwszy roczny wzrost od 2010 roku, podczas gdy w Europie Zachodniej były wyższe o 2,6\% w 2015 roku. Z wydatków tych finansowane były zakupy sprzętu i uzbrojenia. W 2016 roku wyniosły one 375 mld dol., we wcześniejszych latach 2002-2015 wahały się od 201 do 420 mld dol. w roku (SIPRI, 2017).

Silnym impulsem do rozwoju nowoczesnego przemysłu zbrojeniowego był okres pierwszej i drugiej wojny światowej. Wydawać by się mogło, że po drugiej wojnie światowej rozwinięty nad miarę potrzeb okresu pokoju przemysł ten powinien ulegać istotnej redukcji. Jednak jak pokazują dane SIPRI (2017), produkcja i sprzedaż przemysłu zbrojeniowego wzrastały dość szybko także wtedy. Przyczyną tego były pojawiające się co kilka lat $w$ różnych częściach świata konflikty zbrojnie, a przede wszystkim rozpoczęcie tzw. światowego wyścigu zbrojeń między dwoma ówczesnymi mocarstwami zbrojeniowymi: Stanami Zjednoczonymi i Związkiem Radzieckim wraz z grupami państw znajdujących się w blokach polityczno-wojskowych obu liderów zbrojeń. Zaznaczyć też należy, że przemysł ten rozwijał się także dość szybko w krajach wysoko rozwiniętych i rozwijających się, teoretycznie nienależących do obu ugrupowań, czyli we Francji, w Chinach, RPA i Izraelu. W końcu ubiegłego wieku do grupy państw z rozwiniętym przemysłem zbrojeniowym zaczęły dołączać kraje do tej pory występujące w roli importera, np. Indie. 
Rozwojowi przemysłu zbrojeniowego po II wojnie światowej towarzyszyły zmiany strukturalne:

- modernizacja technologiczna - jeszcze do połowy ubiegłego wieku dominujący udział w wartości produkcji przemysłu zbrojeniowego miał przemysł ciężki (stalownie, chemiczny), w miarę upływu czasu w wyrobach tego przemysłu wzrastał udział elektroniki; w uproszczeniu stalowe pancerze zastąpione zostały wszechobecną elektroniką,

- powiększająca się innowacyjność - przemysł ten obecnie na świecie uznaje się za wiodący w zakresie stosowania innowacji i ogólnie postępu technicznego; przykładowo w USA poziom wydatków związanych z innowacjami w pięciu czołowych firmach tej branży w stosunku do wartości sprzedaży przekracza 14\%, podczas gdy w pięciu wiodących firmach amerykańskich branży IT (Microsoft, Google, IBM, Intel, Cisco) to zaledwie nieco ponad 2\% (Steinbock, 2014),

- specjalizacja - rosnąca konkurencyjność w globalizującej się gospodarce światowej wymusiła konieczność specjalizacji nawet w największych firmach zbrojeniowych na świecie; jeśli jest podejmowana dywersyfikacja produkcji, to raczej dotyczy ona wytwarzania wyrobów niezwiązanych z wojskiem,

- konsolidacja przedsiębiorstw - jest realizowana nie tylko w celu eliminacji konkurencji i zdobycia rynków, ale koncentracji środków na badania i rozwój, które stanowią nieporównywalnie duży koszt w tym przemyśle w stosunku do innych przemysłów.

Ostatnie wymienione zmiany są przedmiotem dalszych rozważań.

\section{KONSOLIDACJA PRZEDSIĘBIORSTW W PRZEMYŚLE ZBROJENIOWYM NA ŚWIECIE}

Konsolidacja przedsiębiorstw w przemyśle zbrojeniowym była jedną z bardziej widocznych zmian strukturalnych, zauważalne są też istotne różnice w amerykańskim i zachodnioeuropejskim modelu konsolidacji.

Model amerykański konsolidacji przedsiębiorstw tego przemysłu to głównie fuzje przedsiębiorstw - w uproszczeniu polega to na tym, że to, co kilka lat wcześniej wytwarzało np. 50 przedsiębiorstw, po połączeniu robi tylko pięć. W Stanach Zjednoczonych proces konsolidacji następował szczególnie silnie w latach pięćdziesiątych i sześćdziesiątych ubiegłego wieku, kiedy z kilku tysięcy niewielkich firm - wojskowych dostawców sprzętu wojskowego - wyłoniła się w wyniku fuzji i przejęć grupa kilkudziesięciu większych podmiotów. W konsekwencji coraz większe firmy przejmowały coraz większe firmy lub łączyły się z nimi. W 1994 roku znana firma lotnicza Northrop Corporation przejęła wytwórnię lotniczą Grumman Aircraft Engineering Corporation i przyjęła nazwę Northrop Grumman Corporation. W 1997 roku Boeing przejął inną kluczową na rynku firmę lotniczą McDonnell Douglas, zaś w 2015 roku firma Lockheed Martin przejęła inną wielką firmę produkującą śmigłowce Sikorsky Aircraft Corporation. Całą ścianę w budynku zarządu jednego z głównych zakładów produkcyjnych Lockheed Martin w Fort Worth (w tym miejscu produkowano dla Polski samoloty F16) zajmuje tablica obrazująca konsolidację ok. 200 firm, które w latach 1948-2015 stworzyły największą firmę zbrojeniową na świecie.

W następstwie tych procesów ukształtowała się tzw. wielką piątka, czyli pięć koncernów zatrudniających od 60 do 150 tys. pracowników każdy. Są to koncerny typowo 
wojskowe, z mniejszościowym udziałem komponentu cywilnego, takie jak: Lockheed Martin (samoloty, międzykontynentalne pociski balistyczne), Raytheon (systemy obrony powietrznej i antybalistycznej, pociski samosterujące, okręty, bomby inteligentne i systemy naprowadzania, pociski rakietowe), General Dynamics (okręty, morskie i lądowe systemy walki), Northrop Grumman Corporation (okręty, systemy obrony antybalistycznej, systemy dowodzenia pola walki, systemy radarowe, bezzałogowe aparaty latające), jak i wojskowo-cywilny koncern z produkcją wojskową i - nie mniejszą - cywilną Boeing (samoloty). Według SIPRI (2017) wielka amerykańska piątka po procesach koncentracji produkcji lokuje się na pierwszych miejscach na świecie pod względem przychodów ze sprzedaży.

W Europie Zachodniej procesy konsolidacji następowały znacznie później niż w Stanach Zjednoczonych, bo w latach siedemdziesiątych i osiemdziesiątych, i nie były one przeważającym sposobem łączenia potencjałów firm w tym przemyśle. Dominowała raczej koncepcja budowy przemysłu zbrojeniowego w strukturach ponadnarodowych i koncentracja sił i środków wokół wspólnych programów badawczo-produkcyjnych. Jako przykłady można tu wskazać firmę BAE System, trzecią pod względem wielkości firm zbrojeniowych na świecie, która wprawdzie ma siedzibę na terenie Wielkiej Brytanii, ale powstała dopiero w 1999 roku z połączenia British Aerospace i Marconi Electronic System - części zbrojeniowej firmy General Electric Company. Zaś w 2000 roku w wyniku fuzji trzech narodowych firm: niemieckiej DASA, hiszpańskiej CASA oraz francuskiej Aerospatiale Matra, powstał koncern EADS (European Aeronautic Defence and Space Company). W 2013 roku EADS połączył się z Airbusem i od 2 stycznia 2014 roku ma nową nazwę Airbus Group. Tę firmę traktuje się już jako firmę transeuropejską i zajmuje ona siódmą pozycję na liście światowych firm zbrojeniowych. 0 procesach koncentracji w polskim przemyśle obronnym szerzej w literaturze (Lewandowski, 2011; Pacek, 2014; Jędrych, Klimek 2016).

Analizując, nawet w pobieżny sposób, dane ilustrujące lokalizację przemysłu zbrojeniowego na świecie po tych procesach konsolidacji, można byłoby w uproszczeniu przyjąć, że połowa tego przemysłu to Stany Zjednoczone, zaś druga połowa przypada na kilkanaście innych krajów, z reguły najbardziej rozwiniętych gospodarczo. Jednak sama liczba firm amerykańskich na listach największych firm zbrojeniowych nie pokazuje w pełni różnicy pomiędzy przemysłem amerykańskim a resztą świata. Według danych SIPRI za 2015 rok wśród 100 największych firm zbrojeniowych znajduje się: 39 firm amerykańskich (39\%), 11 rosyjskich, dziewięć brytyjskich, siedem południowokoreańskich, sześć francuskich. Po trzy firmy ma Izrael, Niemcy, Indie, Japonia, po dwie - Włochy, Turcja, Szwajcaria. Pozostałe kraje reprezentuje na tej liście jeden podmiot. Są to: Szwecja, Singapur, Polska, Australia, Belgia, Kanada, Norwegia, Ukraina, Brazylia. Jeden podmiot - Airbus Group, ma w klasyfikacjach międzynarodowych przynależność transeuropejską. Jeśli jednak z tej listy weźmiemy pierwszych 20 największych, to wśród nich znajduje się: 11 firm amerykańskich (55\%), trzy rosyjskie, dwie brytyjskie, dwie francuskie, jedna włoska, jedna transeuropejska. Różnicę między firmami amerykańskimi a i innymi lepiej pokazuje nie liczba firm, a zestawienie wartości sprzedaży, zysku i liczby zatrudnionych pracowników. W 2015 roku łączna wartość sprzedaży wyrobów militarnych 100 największych na świecie firm zbrojeniowych wyniosła 383830 mln dol., w tym firm: amerykańskich $209680 \mathrm{mln}$ dol. (54,6\%), brytyjskich $39440 \mathrm{mln}$ dol. (10,3\%), francuskich $34490 \mathrm{mln}$ dol. (9,0\%), rosyjskich $30130 \mathrm{mln}$ dol. $(7,8 \%)$ (tab. 1). 
Tab. 1. Największe firmy zbrojeniowe na świecie w 2015 roku

\begin{tabular}{|c|c|c|c|c|c|c|c|}
\hline Lp. & Nazwa & Kraj & $\begin{array}{c}\text { Sprzedaż } \\
\text { wyrobów } \\
\text { militarnych }\end{array}$ & $\begin{array}{c}\text { Sprzedaż } \\
\text { ogółem } \\
\text { mld dol. }\end{array}$ & $\begin{array}{c}\% \\
4: 5\end{array}$ & $\begin{array}{c}\text { Zysk } \\
\text { mld } \\
\text { dol. }\end{array}$ & $\begin{array}{c}\text { Liczba } \\
\text { zatrudnionych } \\
\text { (w tys.) }\end{array}$ \\
\hline 1 & Lockheed Martin Corp. & USA & 36,4 & 46,1 & 79 & 3,6 & 126,0 \\
\hline 2 & Boeing & USA & 28,0 & 96,1 & 29 & 5,2 & 161,4 \\
\hline 3 & BAE Systems & Wlk. Brytania & 25,5 & 27,4 & 93 & 1,5 & 82,5 \\
\hline 4 & Raytheon & USA & 21,8 & 23,2 & 94 & 2,1 & 61,0 \\
\hline 5 & Northrop Grumman Corp. & USA & 20,1 & 23,2 & 86 & 2,0 & $65,0 w$ \\
\hline 6 & General Dynamics Corp. & USA & 19,2 & 31,5 & 61 & 3,0 & 99,9 \\
\hline 7 & Airbus Group & Europa & 12,9 & 71,5 & 18 & 3,0 & 136,6 \\
\hline 8 & United Technologies Corp. & USA & 9,5 & 61,0 & 16 & 4,4 & 197,2 \\
\hline 9 & Finmeccanica & Włochy & 9,3 & 14,4 & 65 & 0,6 & 47,2 \\
\hline 10 & L-3 Communications & USA & 8,8 & 10,5 & 84 & 0,3 & 38,0 \\
\hline 11 & Thales & Francja & 8,1 & 15,6 & 52 & 0,9 & 62,2 \\
\hline 12 & $\begin{array}{l}\text { Huntington Ingalls } \\
\text { Industr. }\end{array}$ & USA & 6,7 & 7,0 & 96 & 0,4 & 35,5 \\
\hline 13 & Almaz-Antey & Rosja & 6,6 & 7,0 & 95 & - & - \\
\hline 14 & Safran & Francja & 5,0 & 19,3 & 26 & 1,6 & 70,1 \\
\hline 15 & Harris Corp. & USA & 4,9 & 7,5 & 66 & 0,3 & 21,0 \\
\hline 16 & Rolls-Royce & Wlk. Brytania & 4,8 & 20,4 & 23 & 1,7 & 50,5 \\
\hline 17 & United Aircraft Corp. & Rosja & 4,6 & 5,8 & 80 & $(1,8)$ & - \\
\hline 18 & Bechtel Corp. & USA & 4,6 & 32,3 & 14 & - & 53,0 \\
\hline 19 & United Shipbuilding Corp. & Rosja & 4,5 & 5,2 & 87 & 0,2 & - \\
\hline 20 & Booz Allen Hamilton & USA & 3,9 & 5,4 & 72 & 0,3 & 22,6 \\
\hline 21 & Textron & USA & 3,7 & 13,4 & 27 & 0,7 & 35,0 \\
\hline 22 & Babcock Int. Group & Wlk. Brytania & 3,4 & 7,4 & 46 & 0,6 & - \\
\hline 23 & Honeywell International & USA & 3,4 & 38,6 & 9 & 4,8 & 129,0 \\
\hline 24 & DCNS & Francja & 3,3 & 3,4 & 98 & 0,1 & 127,7 \\
\hline 25 & Russian Helicopters & Rosja & 3,3 & 3,6 & 91 & 0,7 & 41,8 \\
\hline 26 & Leidos & USA & 3,0 & 4,7 & 64 & 0,2 & 18,0 \\
\hline 27 & General Electric & USA & 3,0 & 117,4 & 3 & $(6,1)$ & 333,0 \\
\hline 28 & Mitsubishi Heavy Ind. & Japonia & 3,0 & 33,4 & 9 & - & - \\
\hline 29 & Elbit Systems & Izrael & 3,0 & 3,1 & 95 & 0,2 & 12,1 \\
\hline 30 & Rheinmetall & Niemcy & 2,9 & 5,7 & 50 & 0,7 & 20,7 \\
\hline 31 & Science Applications Int. & USA & 2,9 & 4,3 & 66 & 0,1 & 15,0 \\
\hline 32 & $\begin{array}{l}\text { Israel Aerospace } \\
\text { Industries }\end{array}$ & Izrael & 2,8 & 3,7 & 75 & - & - \\
\hline 33 & Saab & Szwecja & 2,6 & 3,2 & 82 & 0,2 & 14,7 \\
\hline 34 & CACI International & USA & 2,5 & 3,7 & 68 & 0,1 & 19,9 \\
\hline 35 & Tactical Missiles Corp. & Rosja & 2,4 & 2,5 & 96 & 0,2 & 44,1 \\
\hline 36 & Hindustan Aeronautics & Indie & 2,3 & 2,6 & 91 & 0,5 & - \\
\hline 37 & Kawasaki Heavy Industr. & Japonia & 2,3 & 12,7 & 18 & - & - \\
\hline 38 & Rockwell Collins & USA & 2,2 & 5,2 & 42 & 0,7 & 19,5 \\
\hline 39 & Indian Ordnance Factories & Indie & 2,2 & 2,2 & 98 & - & - \\
\hline 40 & AECOM & USA & 2,2 & 18,0 & 12 & $(0,2)$ & 92,0 \\
\hline$\ldots$ & $\ldots$ & $\ldots$ & $\ldots$ & $\ldots$ & $\ldots$ & $\ldots$ & $\ldots$ \\
\hline 60 & Polska Grupa Zbrojeniowa & Polska & 1,2 & 1,3 & 90 & - & 18,0 \\
\hline
\end{tabular}

Źródło: SIPRI, 2017 
KONSOLIDACJA PRZEDSIĘBIORSTW W POLSKIM PRZEMYŚLE ZBROJENIOWYM

Po I wojnie światowej Polska od początku zmuszona była budować własny przemysł zbrojeniowy. Do 1920 roku wyłącznie rozbudowywano istniejące zakłady, pod kątem szybkiego zwiększenia dostaw dla wojska. Pierwszymi nowymi zakładami zbrojeniowymi, wybudowanymi od podstaw ze środków francuskich i przez francuską firmę, były Polskie Zakłady Nitrat S.A. w Niewiadowie, które powstały w latach 1920-1922 (Jędrych, Klimek, 2016). W 1922 roku Komitet Ekonomiczny Rady Ministrów podjął decyzję o skoncentrowaniu zamówień dla armii wyłącznie w istniejących przedsiębiorstwach państwowych. W związku z tym przy ówczesnym Ministerstwie Spraw Wojskowych powołano Centralny Zarząd Wytwórni Wojskowych - twór organizacyjny skupiający przedsiębiorstwa przemysłu zbrojeniowego. Dodatkowo znacjonalizowano istniejącą od 1898 roku Fabrykę Gerlach i Pulst, tworząc Państwową Fabrykę Karabinów w Warszawie. W 1922 roku powołano Państwową Fabrykę Amunicji w Skarżysku (choć przedsiębiorstwo to nie miało jeszcze tej wielkości, jaką osiągnęło w latach 1938-1939), w 1927 roku uruchomiono produkcję w nowej Fabryce Broni w Radomiu. Mocnym impulsem rozwoju tego przemysłu było podjęcie decyzji o budowie Centralnego Okręgu Przemysłowego (COP), czyli 16 nowych zakładów zbrojeniowych oraz kilkunastu innych zakładów energetycznych, chemicznych i metalowych. Działania te spowodowały, że w 1939 roku w skład polskiego przemysłu obronnego wchodziło kilkadziesiąt podmiotów, w tym m.in. 15 fabryk karabinów i dział, 11 fabryk amunicji, osiem zakładów lotniczych, dwie fabryki sprzętu łączności. Zdaniem ekspertów, przemysł ten był jednym z najsilniejszych w skali świata (Jędrych, Klimek, 2016). Przemysł ten posiadał moce produkcyjne kilkukrotnie większe niż praktycznie nieistniejący wówczas amerykański przemysł zbrojeniowy i co najmniej porównywalne z przemysłem niemieckim. Paradoks polega na tym, że w latach 1938-1939 największe polskie zakłady zbrojeniowe dopiero rozpoczynały produkcję, przemysł niemiecki zrobił to kilka lat wcześniej. Pełne uruchomienie nowych zakładów planowano w Polsce na 1941 rok. Szczegółowe opisy rozwoju polskiego przemysłu obronnego w czasach międzywojennych są przedmiotem licznych publikacji (Gołębiowski, 1985; 1990; Kazimierski, 2009; Jędrych, Klimek, 2016).

Polski przemysł zbrojeniowy po II wojnie światowej praktycznie nie istniał. Wprawdzie do pracy zgłosiło się wielu pracowników z okresu przedwojennego i wojennego, a hale zakładów produkcyjnych COP pozostały w niemal nienaruszonym stanie (były zlokalizowane zbyt daleko, biorąc pod uwagę zasięg ówczesnych bombowców alianckich), jednak już w pierwszych miesiącach pobytu wojsk radzieckich na tym terenie wywieziono na wschód większość maszyn i urządzeń produkcyjnych. Już 20 lutego 1945 roku Stalin wydał rozporządzenie nr 7558 dotyczące spraw polskich. W punkcie 6b zapisy tego dokumentu wskazywały, że wywozowi do Związku Radzieckiego z terytorium Polski podlegają urządzenia, materiały oraz produkty konieczne do prowadzenia wojny, które pochodzą z niemieckich zakładów lub też zakładów rozbudowanych przez Niemców w czasie wojny. Paradoksalnie więc w latach pięćdziesiątych, kiedy na całym świecie bardzo szybko wzrastał popyt na sprzęt i uzbrojenie z uwagi na okres zimnej wojny i konflikty w różnych częściach świata, polski przemysł nie miał co i jak wyprodukować. Kiedy zaś wyposażono zakłady przemysłowe w latach sześćdziesiątych, zapotrzebowanie na świecie na wyroby przemysłu zbrojeniowego znacznie zmalało. Nie oznaczało to jednak stagnacji tego przemysłu. Silny impuls do 
jego rozwoju stanowiły duże zamówienia rozbudowującej się polskiej armii, krajów Układu Warszawskiego oraz krajów arabskich, które po wojnie znalazły się w obszarze wpływów tzw. bloku wschodniego, m.in.: Iraku, Iranu, Egiptu, Algierii, a także krajów Ameryki Południowej i Azji. W latach osiemdziesiątych polski przemysł zbrojeniowy to ponad 150 państwowych firm rozlokowanych przede wszystkim w Polsce południowo-wschodniej i centralnej. Nieomal w całości zajmował się on wytwarzaniem wyrobów specjalnych dla liczącej ponad 400 tys. żołnierzy armii polskiej, był też zaliczany do wiodących przemysłów w zakresie wartości eksportu. Szczytowe zdolności wytwórcze krajowe zakłady zbrojeniowe osiągnęły w latach 1985-1988 - produkowały większość systemów uzbrojenia używanego w Wojsku Polskim i zapewniały uzbrojenie dla armii kilkunastu krajów. O rozwoju polskiego przemysłu obronnego po II wojnie światowej szerzej w literaturze pisali Z. Kazimierski (2005) i J. Jaworski (2006).

Kryzys ekonomiczny w polskim przemyśle zbrojeniowym na początku lat dziewięćdziesiątych spowodowały dwa czynniki: utrata tradycyjnych rynków zbytu w krajach arabskich oraz drastyczne ograniczenie zamówień ze strony polskiej armii, spowodowane brakiem środków w budżecie. Ponadto potencjalne nowe rynki zbytu w krajach Europy Zachodniej były dla polskiego przemysłu niedostępne, nie tyle z uwagi na poziom technologii, co odmienność produkowanego uzbrojenia i sprzętu, niezgodnego ze standardami NATO. Pierwszym krokiem w kierunku restrukturyzacji było ustanowienie na początku lat dziewięćdziesiątych w budżecie państwa, w ramach Centralnego Programu Mobilizacji Gospodarki, środków finansowych na utrzymanie tzw. nieczynnych mocy produkcyjnych. Była to swoistego rodzaju „kroplówka”, która pozwalała firmom zbrojeniowym przynajmniej wypłacać pracownikom wynagrodzenia.

Pierwsza poważna (czyli taka, która wyszła poza fazę projektów wewnętrznych na poziomie ministerstwa) próba konsolidacji oparta była na opracowanym w Ministerstwie Gospodarki „Programie restrukturyzacji przemysłu obronnego i wsparcia w zakresie modernizacji technicznej Sił Zbrojnych RP”. Program przewidywał utworzenie Narodowego Funduszu Przemysłu Obronnego (NAFPO), do którego miały zostać wniesione akcje 31 spółek tego przemysłu, oraz dziewięć ośrodków badawczo-rozwojowych. Poza NAFPO planowano pozostawić tzw. wojskowe zakłady remontowo-produkcyjne. Natomiast dotychczasowe 14 spółek tego przemysłu, o mniejszym znaczeniu dla obronności, przeznaczono do prywatyzacji. Program był przedstawiony na posiedzeniu Rady Ministrów 2 lutego 1999 roku. Wprawdzie uzyskał wstępną akceptację, ale Rada Ministrów nie zgodziła się na podstawowy element programu, czyli na konsolidację przedsiębiorstw.

Kolejna próba konsolidacji przemysłu zbrojeniowego miała miejsce w 2002 roku. Na podstawie opracowanej „Strategii przekształceń strukturalnych przemysłowego potencjału obronnego w latach 2002-2005”, dokumentu przyjętego przez Radę Ministrów 14 maja 2002 roku, rozpoczął się proces konsolidacji. Zakładano utworzenie grup kapitałowych:

- grupy amunicyjno-rakietowo-pancernej, składającej się z 16 spółek (PHZ Bumar Sp. z o.o. w Warszawie, ZM Mesko S.A. w Skarżysku Kamiennej, ZM Dezamet S.A. w Nowej Dębie, WSK PZL Warszawa II S.A. w Warszawie, ZPS Sp. z o.o. w Pionkach, ZM Kraśnik Sp. z o.o. w Kraśniku, TM Pressta S.A. w Bolechowie, ZM Bumar Łabędy S.A. w Gliwicach, PCO S.A. w Warszawie, CNPEP Radwar S.A. w Warszawie, ZM Tarnów S.A. w Tarnowie, ZM PZL Wola S.A. w Warszawie, Fabryki Broni 
„ŁUCZNIK-RADOM” Sp. z o.o. w Radomiu, PSO Maskpol S.A. w Konieczkach, ZCh Nitro-Chem S.A. w Bydgoszczy, PHU Cenrex Sp. z o.o. w Warszawie,

- grupy lotniczo-radioelektronicznej, w skład której miało wejść pięć spółek (Agencja Rozwoju Przemysłu S.A. w Warszawie, Polskie Zakłady Lotnicze Sp. z o.o. w Mielcu, WSK PZL Świdnik S.A. w Świdniku, ZR Radmor S.A. w Gdyni, PHZ Cenzin Sp. z o.o. w Warszawie).

Procesy te rozpoczęły się w 2002 roku, niezwłocznie po przyjęciu programu. Pierwszą grupę utworzono poprzez podwyższenie kapitału zakładowego Przedsiębiorstwa Handlu Zagranicznego BUMAR Sp. z o.o. w Warszawie i objęcie udziałów w podwyższonym kapitale przez Skarb Państwa w zamian za wniesione akcje. Akcje spółek drugiej grupy wniesiono w tym samym trybie do Agencji Rozwoju Przemysłu S.A. w Warszawie.

W kolejnych latach PHZ Bumar Sp. z o.o. przekształcono w Polski Holding Obronny Sp. z o.o. (PHO). Do 2014 roku Polski Holding Obronny był grupą kapitałową łączącą ponad 20 spółek polskiego przemysłu zbrojeniowego w Polsce, a tym samym największym producentem i dostawcą uzbrojenia w Polsce.

Wobec niezadowalających wyników PHO Skarb Państwa utworzył w 2013 roku Polską Grupę Zbrojeniową, prowadząc konsolidację przemysłu zbrojeniowego w dwóch etapach. W marcu 2015 roku zakończono drugi etap konsolidacji.

\section{AKTUALNA STRUKTURA SKONSOLIDOWANEGO POLSKIEGO PRZEMYSŁU ZBROJENIOWEGO}

W strukturze polskiego przemysłu zbrojeniowego występują trzy grupy podmiotów:

1. holding ponad 60 spółek Skarbu Państwa lub spółek z większościowym udziałem Skarbu Państwa zgrupowanych w Polskiej Grupie Zbrojeniowej S.A. (PGZ) z siedzibą w Radomiu, o profilu produkcji dla wojsk lądowych (pojazdy, artyleria, broń strzelecka, amunicja),

2. holding pięciu spółek z polskim kapitałem prywatnym, tworzony „od podstaw” na bazie spółki-matki WB Electronics z siedzibą w Warszawie o profilu urządzeń elektroniki, łączności i rozpoznania;

3. kilka byłych państwowych podmiotów o profilu lotniczym, prywatyzowanych w końcu lat dziewięćdziesiątych, których właścicielami są największe firmy zbrojeniowe z USA i Europy Zachodniej.

Polska Grupa Zbrojeniowa to ponad 60 spółek, około 4,5 mld zł przychodów ze sprzedaży w skali roku oraz około 18 tys. zatrudnionych. Firmy należące do Polskiej Grupy Zbrojeniowej działają głównie w branży zbrojeniowej, stoczniowej, offshore, nowych technologii, finansów i nieruchomości, niemal w każdym województwie (w 12 na 16). W tab. 2-5 dla potrzeb tego artykułu pogrupowano je według lokalizacji:

1. południowo-zachodnia część kraju (województwa: podkarpackie, świętokrzyskie, lubelskie, małopolskie, czyli spółki na terenach b. COP),

2. centralna część Polski (w szczególności spółki w Warszawie, Łodzi, Bydgoszczy, Poznaniu i okolicznych miejscowościach),

3. południowa i południowo-zachodnia część Polski (województwa śląskie i dolnośląskie),

4. północna część kraju (województwo pomorskie i zachodniopomorskie). 
Tab. 2. Najważniejsze spółki Polskiej Grupy Zbrojeniowej S.A. zlokalizowane w Polsce południowo-wschodniej

\begin{tabular}{|c|c|c|}
\hline Lp. & Nazwa & Podstawowy profil działalności \\
\hline 1 & $\begin{array}{l}\text { Huta Stalowa Wola S.A. w Stalowej } \\
\text { Woli }\end{array}$ & $\begin{array}{l}\text { haubice samobieżne, artyleryjskie wozy dowodzenia, wozy } \\
\text { dowódczo sztabowe }\end{array}$ \\
\hline 2 & $\begin{array}{l}\text { Zakłady Mechaniczne Tarnów S.A. } \\
\text { w Tarnowie }\end{array}$ & $\begin{array}{l}\text { uzbrojenie strzeleckie, pokładowe i broń wsparcia } \\
\text { ogniowego, systemy przeciwlotnicze, systemy kontenerowe }\end{array}$ \\
\hline 3 & MESKO S.A. w Skarżysku-Kamiennej & $\begin{array}{l}\text { amunicja małokalibrowa, średniokalibrowa, moździerzowa, } \\
\text { czołgowa, artyleryjska, zestawy przeciwlotnicze, zestawy } \\
\text { przeciwpancerne i rakiety }\end{array}$ \\
\hline 4 & $\begin{array}{l}\text { Zakłady Metalowe DEZAMET S.A. } \\
\text { w Nowej Dębie }\end{array}$ & granatniki, bomby, granaty, amunicja, zapalniki \\
\hline 5 & $\begin{array}{l}\text { Wojskowe Zakłady Łączności nr } 2 \text { S.A. } \\
\text { w Czernicy }\end{array}$ & $\begin{array}{l}\text { kabiny szczelne elektromagnetyczne, aparatownie, wozy } \\
\text { dowodzenia, urządzenia techniki cyfrowej }\end{array}$ \\
\hline 6 & $\begin{array}{l}\text { Wojskowe Zakłady Inżynieryjne S.A. } \\
\text { w Dęblinie }\end{array}$ & $\begin{array}{l}\text { remonty i modernizacje sprzętu inżynieryjnego, minersko- } \\
\text { rozpoznawczego, saperskiego, pojazdy }\end{array}$ \\
\hline
\end{tabular}

Źródło: PGZ (2017)

Tab. 3. Najważniejsze spółki Polskiej Grupy Zbrojeniowej S.A. zlokalizowane w Polsce centralnej

\begin{tabular}{|r|l|l|}
\hline Lp. & \multicolumn{1}{|c|}{ Nazwa } & \multicolumn{1}{|c|}{ Podstawowy profil działalności } \\
\hline 1 & $\begin{array}{l}\text { Przemysłowe Centrum Optyki S.A. } \\
\text { w Warszawie }\end{array}$ & $\begin{array}{l}\text { wyposażenie indywidualne (gogle, celowniki, lornetki), } \\
\text { wyposażenie wozów bojowych (systemy kierowania ogniem, } \\
\text { systemy ostrzegania, peryskopy, głowice obserwacyjne) }\end{array}$ \\
\hline 2 & PIT-RADWAR S.A. w Warszawie & $\begin{array}{l}\text { radiolokacja, radioelektroniczne systemy rozpoznania, } \\
\text { systemy automatyzacji i dowodzenia }\end{array}$ \\
\hline 4 & $\begin{array}{l}\text { Fabryka Broni ŁUCZNIK-Radom Sp. } \\
\text { Z o.o. w Radomiu } \\
\text { Konstrukcyjno-Technologiczne S.A. } \\
\text { w Warszawie }\end{array}$ & $\begin{array}{l}\text { broń strzelecka (karabinki, pistolety maszynowe, pistolety } \\
\text { samopowtarzalne) }\end{array}$ \\
\hline 5 & $\begin{array}{l}\text { Wojskowe Zakłady Lotnicze nr 4 } \\
\text { w Warszawie } \\
\text { czołgów i wozów bojowych }\end{array}$ & $\begin{array}{l}\text { wojskowe silniki odrzutowe, śmigłowcowe, turbinowe } \\
\text { zespoły rozruchowe }\end{array}$ \\
\hline 6 & $\begin{array}{l}\text { Wojskowe Zakłady Elektroniczne S.A. } \\
\text { w Zielonce }\end{array}$ & $\begin{array}{l}\text { systemy rozpoznawcze, rejestracyjne, ostrzegawcze, } \\
\text { kontrolno-pomiarowe }\end{array}$ \\
\hline 7 & $\begin{array}{l}\text { Wojskowe Zakłady Łączności nr 1 } \\
\text { w Zegrzu }\end{array}$ & $\begin{array}{l}\text { sprzęt łączności, wozy i stanowiska dowodzenia, zespoły } \\
\text { prądotwórcze }\end{array}$ \\
\hline 8 & $\begin{array}{l}\text { Wojskowe Zakłady Lotnicze nr 1 } \\
\text { w Łodzi }\end{array}$ & $\begin{array}{l}\text { naprawy, obsługa i modernizacje śmigłowców, remonty } \\
\text { silników lotniczych }\end{array}$ \\
\hline 9 & $\begin{array}{l}\text { Wojskowe Zakłady Lotnicze nr 2 } \\
\text { w Bydgoszczy }\end{array}$ & $\begin{array}{l}\text { ENemonty i przeglądy samolotów Mig-29, Su-22, F-16,C-130 } \\
\text { remóno }\end{array}$ \\
\hline 11 & WSK „PZL-Kalisz” S.A. & $\begin{array}{l}\text { prefabrykacja rurociągów, zbiorników i konstrukcji } \\
\text { stalowych }\end{array}$ \\
\hline
\end{tabular}

Źródło: PGZ (2017)

Tab. 4. Najważniejsze spółki Polskiej Grupy Zbrojeniowej S.A. zlokalizowane w południowej i południowo-zachodniej Polsce

\begin{tabular}{|c|l|l|}
\hline 1 & $\begin{array}{l}\text { ROSOMAK S.A. w Siemianowicach } \\
\text { Sląskich }\end{array}$ & pojazdy bojowe \\
\hline 2 & $\begin{array}{l}\text { Zakłady Mechaniczne „Bumar- } \\
\text { Łabędy” S.A. w Gliwicach }\end{array}$ & $\begin{array}{l}\text { czołgi, wozy zabezpieczenia technicznego, mosty } \\
\text { towarzyszące }\end{array}$ \\
\hline
\end{tabular}




\begin{tabular}{|c|l|l|}
\hline 3 & $\begin{array}{l}\text { Ośrodek Badawczo-Rozwojowy } \\
\text { Urządzeń Mechanicznych „OBRUM” } \\
\text { w Gliwicach }\end{array}$ & $\begin{array}{l}\text { gąsienicowe wozy bojowe, pojazdy inżynierskie, mosty, } \\
\text { symulatory i trenażery }\end{array}$ \\
\hline 4 & Jelcz Sp. z o.o. we Wrocławiu & samochody ciężarowe, autobusy, samochody pożarnicze \\
\hline 5 & $\begin{array}{l}\text { Przedsiębiorstwo Sprzętu } \\
\text { Ochronnego Maskpol S.A. } \\
\text { w Konieczkach }\end{array}$ & $\begin{array}{l}\text { produkty ochrony balistycznej, przeciwchemicznej } \\
\text { i prewencyjnej }\end{array}$ \\
\hline 6 & Fabryka Kotłów SEFAKO S.A. & kotły \\
\hline 7 & $\begin{array}{l}\text { Zakład Mechaniczny „BUMAR - } \\
\text { MIKULCZYCE” S.A. }\end{array}$ & podzespoły do sprzętu wojskowego \\
\hline 8 & $\begin{array}{l}\text { Wojskowe Zakłady Łączności nr 2 S.A. } \\
\text { w Czernicy }\end{array}$ & $\begin{array}{l}\text { kabiny elektromagnetyczne, aparatownie, zautomatyzowane } \\
\text { wozy dowodzenia, urządzenia techniki cyfrowej }\end{array}$ \\
\hline
\end{tabular}

Źródło: PGZ (2017)

Tab. 5. Najważniejsze spółki Polskiej Grupy Zbrojeniowej S.A. zlokalizowane w północnej

\begin{tabular}{|c|l|l|}
\hline Lp. & \multicolumn{1}{|c|}{ Nazwa } & \multicolumn{1}{|c|}{ Podstawowy profil działalności } \\
\hline 1 & $\begin{array}{l}\text { Stocznia Remontowa „NAUTA” S.A. } \\
\text { w Gdyni }\end{array}$ & budowy i remonty statków i okrętów \\
\hline 2 & $\begin{array}{l}\text { Morska Stocznia Remontowa Gryfia } \\
\text { S.A. w Szczecinie }\end{array}$ & remonty i budowy statków \\
\hline 3 & $\begin{array}{l}\text { Energomontaż-Północ Gdynia S.A. } \\
\text { w Gdyni }\end{array}$ & $\begin{array}{l}\text { wielkogabarytowe konstrukcje stalowe (urządzenia dźwigowe, } \\
\text { konstrukcje podwodne, moduły dla jednostek pływających) }\end{array}$ \\
\hline 4 & $\begin{array}{l}\text { Ośrodek Badawczo-Rozwojowy } \\
\text { Centrum Techniki Morskiej S.A. } \\
\text { w Gdyni }\end{array}$ & $\begin{array}{l}\text { prace badawczo-rozwojowe, projektowe, konstrukcyjno- } \\
\text { technologiczne i doświadczalne }\end{array}$ \\
\hline 5 & $\begin{array}{l}\text { Wojskowe Zakładu Uzbrojenia S.A. } \\
\text { w Grudziądzu }\end{array}$ & $\begin{array}{l}\text { trenażery, symulatory, głowice optoelektroniczne, systemy } \\
\text { identyfikacji, modernizacje i remonty }\end{array}$ \\
\hline
\end{tabular}

Źródło: PGZ (2017)

WB Electronics jest liderem WB Group, największej prywatnej polskiej firmy zbrojeniowej. W skład Grupy wchodzi obecnie pięć firm - WB Electronics S.A., Arex sp. z o.o., Flytronic sp. z o.o., MindMade sp. z o.o. i Radmor S.A. Wykorzystując możliwości wszystkich przedsiębiorstw, WB Group oferuje nowoczesne produkty w dziedzinie elektroniki specjalnej - systemy łączności, kierowania ogniem i platformy bezzałogowe. Pozwoliło to firmie na zbudowanie pozycji technologicznego innowatora, dostarczającego swoje produkty do armii na całym świecie - m.in. do USA, Indii, Malezji, Szwecji, Węgier i Afryki Północnej. Tworzenie WB Group rozpoczęło się w 2009 roku od objęcia przez WB Electronics udziałów we Flytronic Sp. z o.o. Następnie w 2011 roku do Grupy dołączyły trzy firmy - Radmor S.A., Arex sp. z o.o. i MindMade sp. z o.o. (tab. 6).

Tab. 6. Spółki polskiej grupy przemysłu zbrojeniowego WB Group

\begin{tabular}{|c|l|l|}
\hline Lp. & \multicolumn{1}{|c|}{ Nazwa } & \multicolumn{1}{c|}{ Podstawowy profil działalności } \\
\hline & & $\begin{array}{l}\text { prace badawczo-rozwojowe w dziedzinie techniki elektronicznej } \\
\text { i oprogramowania, a także opracowywanie i produkcja systemów } \\
\text { specjalnych, komputerów i terminali o wzmocnionej konstrukcji, środków } \\
\text { łączności telekomunikacji wojskowej, urządzeń do transmisji danych } \\
\text { i integracji wyposażenia elektronicznego pojazdów, tworzenie rozwiązań } \\
\text { w dziedzinie zautomatyzowanych systemów dowodzenia w technologiach } \\
\text { informatycznych i łączności sieciowej }\end{array}$ \\
\hline
\end{tabular}




\begin{tabular}{|c|l|l|}
\hline 2 & Radmor S.A. w Gdyni & $\begin{array}{l}\text { produkcja radiotelefonów doręcznych, przewoźnych i stacjonarnych, } \\
\text { radiomodemów i modułów transmisji danych, wojskowych radiostacji } \\
\text { osobistych, plecakowych i przewoźnych }\end{array}$ \\
\hline 3 & $\begin{array}{l}\text { AREX Sp. z o.o. } \\
\text { w Gdyni }\end{array}$ & $\begin{array}{l}\text { produkcja przetworników pomiarowych różnych wielkości fizycznych, } \\
\text { urządzeń sterowania napędami elektrycznymi, sterowania uzbrojeniem } \\
\text { oraz zestawów treningowych do różnego rodzaju uzbrojenia }\end{array}$ \\
\hline 4 & $\begin{array}{l}\text { Flytronic Sp. z.o.o. } \\
\text { w Gliwicach }\end{array}$ & $\begin{array}{l}\text { prace badawczo-rozwojowe w zakresie mechaniki, elektroniki i informatyki } \\
\text { w obszarze przemysłu lotniczego, produkcja dronów }\end{array}$ \\
\hline 5 & $\begin{array}{l}\text { MindMade Sp. z o.o. } \\
\text { w Warszawie }\end{array}$ & $\begin{array}{l}\text { centrum kompetencyjne i badawczo-rozwojowe, profilowane w kierunku } \\
\text { rynku telekomunikacji, łączności, telemetrii i teleautomatyki, podstawowe } \\
\text { rozwiązania to systemy transmisji danych, Platforma Integracji } \\
\text { Komunikacji (PIK), wielosystemowe rozwiązanie integrujące różne } \\
\text { technologie radiokomunikacyjne, produkcja urządzeń do podwodnej } \\
\text { i bezstykowej transmisji danych i mocy elektrycznej }\end{array}$ \\
\hline
\end{tabular}

Źródło: Grupa WB (2017)

Trzecią grupę przedsiębiorstw zbrojeniowych w Polsce tworzą prywatyzowane byłe spółki Skarbu Państwa o profilu lotniczym, których właścicielami są obecnie największe firmy zbrojeniowe z USA i Europy Zachodniej. De facto są to oddziały zagraniczne koncernów zbrojeniowych, zajmujące się przede wszystkim produkcją, bez prac badawczo-rozwojowych (tab. 7).

Tab. 7. Charakterystyka spółek lotniczych w polskim przemyśle zbrojeniowym

\begin{tabular}{|c|l|}
\hline Lp. & Charakterystyka spółki \\
\hline 1 & $\begin{array}{l}\text { EADS PZL Warszawa-Okęcie S.A. w Warszawie (b. PZL Okęcie S.A.) to najstarsze polskie } \\
\text { zakłady lotnicze (1928 rok), firma opracowała i wdrożyła do produkcji } 22 \text { modele samolotów, } \\
\text { wyprodukowała } 6000 \text { samolotów, eksportowała do ponad 30 krajów, w } 2001 \text { roku spółka została } \\
\text { włączona w skład Grupy EADS (obecnie Airbus Military), wchodzącej w skład transeuropejskiej } \\
\text { grupy zbrojeniowej, zajmującej siódmą pozycję pod względem wielkości w światowym przemyśle } \\
\text { zbrojeniowym - Airbus Group (http://www.aero-plan.org/pl/eads-pzl-warszawa-okecie-s-a). }\end{array}$ \\
\hline \multirow{2}{*}{2} & $\begin{array}{l}\text { Pratt \& Whitney Rzeszów S.A. w Rzeszowie (b. Wytwórnia Sprzętu Komunikacyjnego S.A.) jest } \\
\text { przedsiębiorstwem zajmującym się produkcją komponentów lotniczych i kompletnych jednostek } \\
\text { napędowych. Działalność Spółki opiera się na obszarach: lotniczym, przekładniowym, odlewów } \\
\text { precyzyjnych, narzędziowym i utrzymania ruchu, napraw komponentów silnikowych PWC, } \\
\text { produkcji, remontów i serwisu własnych silników lotniczych (http://www.pwrze.com/o-firmie/ } \\
\text { dzialalnosc/). }\end{array}$ \\
\hline 3 & $\begin{array}{l}\text { Polskie Zakłady Lotnicze Sp. z o.o. - PZL Mielec w Mielcu (b. WSK PZL Mielec S.A.), spółka zależna } \\
\text { Sikorsky Aircraft Corporation, jest największym w Polsce producentem samolotów, rozszerzającym } \\
\text { profil produkcji o wytwarzanie struktur lotniczych i produkcję helikopterów. W 2007 roku 100\% } \\
\text { udziałów Polskich Zakładów Lotniczych Sp. z o.o. zostało zakupione od ARP S.A. przez United } \\
\text { Technologies Holdings S.A. (UTH), spółkę United Technologies Corporation (UTC). W 2015 roku } \\
\text { Sikorsky i PZL Mielec zostały przejęte przez Lockheed Martin (http://www.pzlmielec.pl/). }\end{array}$ \\
\hline 4 & $\begin{array}{l}\text { Wytwórnia Sprzętu Komunikacyjnego „PZL-Świdnik” S.A. w Świdniku to firma z ponad 65-letnim } \\
\text { doświadczeniem, która wyprodukowała więcej niż 7400 śmigłowców, to jedyny polski wytwórca } \\
\text { z pełną zdolnością w zakresie projektowania, badań i rozwoju, integracji systemów, produkcji, } \\
\text { realizacji wsparcia i szkoleń oraz modernizacji śmigłowców (http://www.pzl.swidnik.pl/pl/o- } \\
\text { firmie/profil-firmy/0,-7g,1,122). }\end{array}$ \\
\hline
\end{tabular}

Źródło: podane w tabeli

\section{PODSUMOWANIE}

Obecna struktura polskiego przemysłu zbrojeniowego wskazuje, że - pomimo wielu zmian strukturalnych - spółki usytuowane są w miejscu, w którym budowano ten 
przemysł przed drugą wojną światową. Najważniejsze spółki, niezależnie od ich przynależności do określonej grupy, zlokalizowane są na terenie byłego COP i w Warszawie.

Model struktury polskiego przemysłu zbrojeniowego należy uznać za mieszany, w niewielkim stopniu odpowiadający modelom amerykańskiemu czy preferowanemu w Europie Zachodniej. Bliższy jest on rozwiązaniom występujących w niektórych krajach Europy Środkowo-Wschodniej lub Finlandii, gdzie funkcjonuje narodowy koncern, skupiający ponad 25 przedsiębiorstw tego przemysłu.

Podstawowym problemem jest jednak to, że tak ukształtowana struktura nie zapewnia poprawy konkurencyjności polskiego przemysłu zbrojeniowego wobec szybko nadchodzących zmian w europejskim przemyśle zbrojeniowym. Chodzi tu przede wszystkim o PGZ. Wprawdzie wystąpiła już w poszczególnych grupach specjalizacja: PGZ (wojska lądowe), WB Electronics (elektronika), spółki prywatyzowane (samoloty i śmigłowce), jednak stopień specjalizacji PGZ jest zbyt niski. Tego typu podmiot, zajmujący zaledwie sześćdziesiątą pozycję pod względem wielkości wśród największych firm zbrojeniowych na świecie, nie może produkować wszystkiego dla wojsk lądowych. Jest to rozpraszanie i tak ograniczonych sił i środków. Zasadne było dążenie do zwiększania specjalizacji i wytwarzania 20 , być może 30 produktów, wydłużające $w$ ten sposób serie produkcyjne i zmniejszające koszty. Problemem PGZ jest także struktura holdingowa (ok. 60 większych i mniejszych spółek). Za zdecydowanie lepsze rozwiązanie należałoby uznać powołanie koncernu zbrojeniowego, bez kilkudziesięciu zarządów spółek, ze skoncentrowaną sferą badań i rozwoju oraz eksportu, w którym obecne spółki pełniłyby wyłącznie funkcję zakładów produkcyjnych. Tylko, znając polskie realia, należałoby się wówczas obawiać ambicji lokalnych polityków, z których wielu byłoby prawdopodobnie zainteresowanych utrzymaniem spółek na danym terenie.

I wreszcie wydaje się, że konieczne jest zdefiniowanie roli tego przemysłu dla państwa i społeczeństwa. Z reguły występuje on w każdym państwie, które nim dysponuje, w kilku rolach:

- jako gwarant bezpieczeństwa państwa, który w okresie zagrożenia potrafi zapewnić armii środki walki,

- jako narzędzie polityki, zgodnie z zasadą, która mówi, że silna armia i silny przemysł zbrojeniowy, pozwala budować silną pozycję polityczną kraju,

- jako jeden z filarów eksportu z reguły wysoce rentownych wyrobów,

- jako najnowocześniejszy przemysł z rozbudowaną sferą badawczą, w którym powstaje najwięcej innowacji, które później mają zastosowanie w przemysłach niezwiązanych z armią.

\section{Literatura \\ References}

Gołębiowski, J. (1985). Sektor państwowy w gospodarce Polski międzywojennej. Kraków: Wydawnictwo Naukowe PWN.

Gołębiowski, J. (1990). Przemysł wojenny w Polsce 1918-1939. Kraków: Wydawnictwo Naukowe WSP.

Grupa WB (2017, 18 grudnia). Pozyskano z http://wb.com.pl/

Jaworski, J. (2006). Restrukturyzacja polskiego przemysłu zbrojeniowego. Prace Komisji Geografii Przemysłu Polskiego Towarzystwa Geograficznego, 9, 130-142.

Jędrych, E., Klimek, D. (2016). Przemysł obronny w warunkach globalizacji. International Business and Global Economy, 35(2), 444-453. 
Kazimierski, Z. (2005). Polski przemysł zbrojeniowy w latach 1945-1955. Warszawa: Wyższa Szkoła Działalności Gospodarczej.

Kazimierski, Z. (2009). Polityka państwa polskiego zwłaszcza w zakresie tworzenia, produkcji i rozwoju przemysłu obronnego w latach 1918-2008. W: W. Matejuk (red.). Potrzeba oraz możliwości i dostępne źródła dotyczące tworzenia, rozwoju oraz stanu polskiej techniki przemysłu obronnego (Lata 1918-2008). Warszawa: Polskie Towarzystwo Historii Techniki.

Lewandowski, W. (2011). Polski przemysłowy potencjał obronny w dobie konsolidacji. Bezpieczeństwo Narodowe, 17.

Pacek, B. (2014). Konsolidacja przemysłowego potencjału obronnego w Polsce. Uwarunkowania, dylematy i szanse. Zeszyty Naukowe Akademii Obrony Narodowej, 1(94).

PGZ (2017, 18 grudnia). Polska Grupa Zbrojeniowa. Pozyskano z http://pgzsa.pl/

SIPRI (2017, 18 grudnia). SIPRI yearbook 2017. Armaments, Disarmament and International Security. Pozyskano z https://www.sipri.org/sv/yearbook/2017/summary/sipri-yearbook-2017-summary-swedish

Steinbock, D. (2014). The Challenges for America's Defense Innovation. Washington: The Information Technology \& Innovation Foundation.

Dariusz Klimek, dr nauk ekonomicznych, adiunkt na Wydziale Zarządzania i Inżynierii Produkcji PŁ, wieloletni prezes zarządu spółek Skarbu Państwa i firm zagranicznych, m.in. w przemyśle maszynowym i zbrojeniowym - Grupa Holdingowa Bumar S.A. w Warszawie, Zakłady Sprzętu Precyzyjnego Niewiadów S.A. w Niewiadowie, wiceminister gospodarki, w latach dziewięćdziesiątych inicjator reform i programów rządowych, współautor kilku ustaw reformujących polską gospodarkę, m.in. tzw. ustawy offsetowej, b. przewodniczący Zespołu Rady Ministrów ds. Gotowości Obronnej Gospodarki, b. przewodniczący podzespołu negocjującego akcesję Polski do UE, autor ponad 40 publikacji z zakresu polityki przemysłowej, systemów zarządzania i migracji.

Dariusz Klimek, Ph.D. in Economic Sciences, assistant professor at the Faculty of Management and Production Engineering of Lodz University of Technology, a long-term president of the management board of State Treasury companies and foreign companies, among others in machine and defense industries - Holding Group Bumar S.A. in Warsaw, Zakłady Sprzętu Precyzyjnego Niewiadów S.A. in Niewiadów, a deputy Minister of Economy, in the 1990s, the initiator of reforms and government programs, co-author of several acts reforming the Polish economy, including the so-called offset act, a former president of the Council of Ministers' Team for Defense Readiness, a former chairman of the sub-group negotiating Poland's accession to the EU, an author of over 40 publications in the field of industrial policy, management systems and migration.

\section{Adres/address:}

Politechnika Łódzka

Wydział Zarządzania i Inżynierii Produkcji

ul. Piotrkowska 266, 90-924 Łódź, Polska

e-mail: dariuszklimek2@gmail.com 